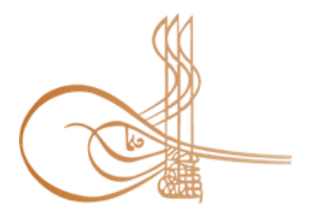

www.turkishstudies.net/social
Turkish Studies - Social Sciences

eISSN: 2667-5617

Research Article / Araştırma Makalesi

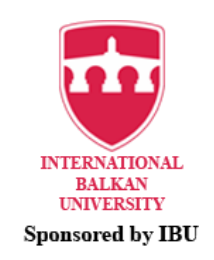

Sponsored by IBU

\title{
İnsan Kaynakları Yönetimi Uygulamaları ile İş Yaşamında Yalnızlık Arasındaki İlişki: Otel İşletmeleri Üzerine Bir Araştırma
}

\author{
The Relationship Between Human Resources Management Practices and Loneliness in The \\ Workplace: A Research on Hotel Enterprises
}

Melda Akbaba*

\begin{abstract}
Effective human resource management practices can significantly affect workplace loneliness of the employees in an organization. Therefore, the main objective of the current research is to identify the relationship between human resource management practices and loneliness in the workplace. Besides, it is aimed to examine whether human resource management practices and loneliness in the workplace differ according to demographic factors. In this vein, 310 employees working in hotel enterprises were selected via random sampling method and interviewed via survey, which is a data collection tool. The results of the correlation analysis, which was conducted to explore the relationship between human resource management practices and employee loneliness in the workplace, report that there is a significant and negative correlation between human resource management practices and loneliness in the workplace. In this context, it can be asserted that the more efficient human resource management practices are the less loneliness, social friendship and emotional deprivation employees will experience in the workplace. On the other hand, the regression analysis results conclude that loneliness in the workplace (dependent variable) is explained by human resource management practices and all correlations between dependent and independent variables are statistically significant. In the current research, it is revealed that human resource management practices and loneliness in the workplace differ according to respondents' gender, age, years of experience in the tourism industry and the organization they work for, human resource management practices differ according to respondents' marital status, and loneliness in the workplace differs according to respondents' educational background.
\end{abstract}

Structured Abstract: Latest developments in today's world create rapid and strong influence on working life. In this respect, enterprises gravitate toward human resource management practices so as to take part in this process of development, to compete and to gain competitive advantage. The concept of human resources encompasses the potential external workforce that could benefit the organization as well as the existing workforce within the organization. Human resources are referred to as a management approach that considers the human production factor as the most important resource to invest in and aims at proliferation of the workforce that can utilize technology and knowledge and constantly improves itself on the basis of creativity

* Dr. Öğr. Üyesi, Kilis 7 Aralık Üniveritesi, Turizm ve Otelcilik Meslek Yüksekokulu, Otel, Lokanta ve İkram Hizmetleri Bölümü

Assistant Professor, Kilis 7 Aralik University, Vocational School of Tourism and Hotel Management, Hotel, Restaurant and Catering Services Department

ORCID 0000-0001-8701-017X

meldaharbali@gmail.com

Cite as/ Atıf: Akbaba, M. (2020). İnsan kaynakları yönetimi uygulamaları ile iş yaşamında yalnızlık arasındaki ilişki: otel işletmeleri üzerine bir araştırma. Turkish Studies - Social, 15(4), 1701-1716. https://dx.doi.org/10.29228/TurkishStudies.43159

Received/Geliş: 24 April/Nisan 2020

Accepted/Kabul: 20 June/Haziran 2020

Copyright $($ INTAC LTD, Turkey

Checked by plagiarism software

Published/Yayın: 25 June/Haziran 2020

CC BY-NC 4.0 
(Güler, 2006: 17). In this study, Human resource management (HRM) practices are examined within the framework of rewarding, salary system, training practices and performance appraisal, communication with the employee, and career system. Loneliness in the workplace (LW) means that the person working in an organization feels lonely among other employees. In other words, it refers to the fact that the employee fails in establishing social relationships with other employees, feels alienated and lonely (Koçel, 2014: 531). Workplace loneliness is examined by Wright et al. (2006) in two dimensions as social friendship and emotional loneliness. Within the framework of the assumption that HRM practices will trigger LW, the main objective in the current study is to determine the relationship between HRM practices and LW. It is also aimed to examine whether human resource management practices and loneliness in the workplace differ according to demographic factors. In the light of the research objective, the research hypotheses are proposed as follows:

H1: There is a significant and negative relationship between HRM and LW.

$\mathrm{H} 2$ : There is a negative correlation between the rewarding dimension of HRM practices and (a) social friendship and (b) emotional loneliness dimensions of LW.

H3: There is a negative correlation between the salary system dimension of HRM practices and (a) social friendship and (b) emotional loneliness dimensions of LW.

$\mathrm{H} 4$ : There is a negative correlation between the training practices and performance appraisal dimension of HRM practices and (a) social friendship and (b) emotional loneliness dimensions of LW.

H5: There is a negative correlation between the communication with the employee dimension of HRM practices and (a) social friendship and (b) emotional loneliness dimensions of LW.

H6: There is a negative correlation between the career system dimension of HRM practices and (a) social friendship and (b) emotional loneliness dimensions of LW.

H7: (a) HRM and (b) LW differ on the basis of gender.

H8: (a) HRM and (b) LW differ on the basis of marital status.

H9: (a) HRM and (b) LW differ on the basis of age.

H10: (a) HRM and (b) LW differ on the basis of educational background.

H11: (a) HRM and (b) LW differ on the basis of years of experience in the tourism industry.

H12: (a) HRM and (b) LW differ on the basis of years of experience in the organization they work for.

The data obtained through survey, which is the data collection method employed in the current study, was analyzed on the statistics program. In the research, correlation analysis was performed to determine the relationship between HRM practices in hotel enterprises and LW of employees. Besides, it was analyzed whether HRM and LW differ according to demographic characteristics of the respondents.

According to the correlation analysis results in the study, which was conducted to determine the relationship between HRM practices and employee loneliness in the workplace, there is a significant and negative relationship between HRM practices and LW in hotel enterprises. In this context, it can be asserted that the level of loneliness, social friendship and emotional deprivation of employees will decrease as the efficiency of human resource management practices increases. On the other hand, the regression analysis results indicate that loneliness in the workplace (dependent variable) is explained by human resource management practices and all correlations between dependent and independent variables are statistically significant. In the current research, it is revealed that human resource management practices and loneliness in the workplace differ according to respondents' gender, age, years of experience in the tourism industry and the organization they work for, human resource management practices differ according to respondents' marital status, and loneliness in the workplace differs according to respondents' educational background. Consequently, H1, H2a, H2b, H3a, H3b, H4, H4b, H5a, H5b, H6a, H6b, H7a, H7b, H8a, H9a, H9b H10b, $\mathrm{H} 11 \mathrm{a}, \mathrm{H} 11 \mathrm{~b}, \mathrm{H} 12 \mathrm{a}$ and H12b are supported whereas H8b and H10a are rejected.

In the light of the analysis results within the scope of HRM practices in organizations involving rewarding, salary system, training practices and performance appraisal, communication with the employee and career system, the fact that employees with superior success are granted with additional rewards; that the rewarding system is equitable and grounded on employee success and performance; that employees earn sufficient salary to meet their personal needs and the needs of their families; that they receive a salary that is the equivalent of their efforts; that they are provided with training opportunities whenever necessary and gain new skills thanks to those trainings; that there is an equitable performance appraisal system in the organization; that there are no communication problems between employees and the supervisor; that employees' ideas and suggestions are welcome and respected; that employees having good performance in 
the organization are promoted fairly and the promotion system is sufficient at meeting the expectations of the employees may facilitate that employees do not feel that their colleagues are distant from them and they are not emotionally distant to their colleagues, have no feelings of alienation in the workplace, feel satisfied with their relationships in the organization, enjoy the dominant sense of friendship in the organization, have no feelings of being excluded from and disconnected with other employees. Hence, employees will utilize creativity more, have higher work performance, motivation and job satisfaction and less turnover intention, which will reduce staff turnover rate and save the hotel enterprises from extra costs.

Keywords: Human Resources Management, Loneliness in The Workplace, Hotel Enterprises.

Öz: İnsan kaynakları yönetimi uygulamalarının etkin bir şekilde olması örgüt içerisinde çalışanların iş yaşamında yalnızlıklarını da önemli ölçüde olumlu olarak etkileyebilecektir. Bu nedenle araştırmada temel amaç insan kaynakları yönetimi uygulamaları ile iş yaşamında yalnızlık arasındaki ilişkinin belirlenmesidir. Ayrıca insan kaynakları yönetimi uygulamalarının ve iş yaşamında yalnızlığın demografik faktörler açısından farklılaşmalarına bakılması da amaçlanmıştır. Bu amaç çerçevesinde basit tesadüfî örneklem yöntemi kullanılarak otel işletmelerinde istihdam edilen 310 çalışana veri toplama yöntemi olan anket aracılığıyla ulaşılmıştır. Otel işletmelerinde insan kaynakları yönetimi uygulamaları ile çalışanların iş yaşamında yalnızlıkları arasındaki ilişkinin belirlenmesine yönelik yapılan bu araştırmada korelasyon analizinin sonucuna göre otel işletmelerinde insan kaynakları yönetimi uygulamaları ile iş yaşamında yalnızlık arasında anlamlı düzeyde negatif yönlü yüksek bir ilişki olduğu tespit edilmiştir. Bu kapsamda insan kaynakları yönetimi uygulamalarının etkinliği arttıkça çalışanların iş yaşamında yalnızlık, sosyal arkadaşlık ve duygusal yoksunluk düzeylerinin azalacağını söylemek mümkündür. Bununla birlikte regresyon analizi sonuçlarına göre iş yaşamında yalnızlık bağımlı değişkeni insan kaynakları yönetimi uygulamaları tarafından açıklanabilmekte ve anlamlılık değerlerine göre bağımlı ve bağımsız değişkenler arasındaki tüm ilişkilerin anlamlı olduğu sonucuna ulaşılmıştır. Araştırmada katılımcıların cinsiyet, yaş, turizm sektöründe ve işletmede çalışma süresine göre insan kaynakları yönetimi uygulamaları ve iş yaşamında yalnızlığın, katılımcıların medeni durum değişkenine göre insan kaynakları yönetimi uygulamalarının, katılımcıların eğitim durum değişskenine göre iş yaşamında yalnızlığın farklılık gösterdiği belirlenmiştir.

Anahtar Kelimeler: İnsan Kaynakları Yönetimi, İş Yaşamında Yalnızlık, Otel İşletmeleri.

\section{Giriş}

Bacasız sanayi olarak nitelendirilen otel işletmelerinde insan kaynă̆1, örgütlerin amaçlarına ulaştırılmasında ve farklılık yaratılmasında anahtar rol üstlenmekte ve örgütler adına insan kaynakları yönetimi (IKY) uygulamalarının etkin olmasıyla birlikte çalışanlarından azami düzeyde fayda elde etmeleri zorunluluk haline gelmiştir. Bu bağlamda örgütlerin dikkate alması gereken en önemli nokta çalışanlarını iş yaşamında yalnız hissettirmeyecek bir düzeyde olmasıdır. Çünkü otel işletmelerinde İKY uygulamalarına bağlı olarak çalışanların davranışları şekillenmektedir. Söz konusu uygulamaların olumlu seviyede olması çalışanların davranışlarını olumlu olarak etkilemektedir. $\mathrm{Bu}$ sayede işletmeler amaçlarına ulaşmada kolaylık, farklılık yaratarak rekabet üstünlüğ̈̈ ve verimlilik elde ederek sürdürülebilirliğini sağlayabilecek ve çalışanlarda bireysel amaçlarına ulaşabilecektir.

İKY, örgütlerin en değerli varlığı olan çalışanların etkin bir şekilde yönetimine yönelik geliştirilen stratejik ve tutarlı bir yaklaşım olarak örgüt içinde yüksek performansa sahip işgücünün kazanılması, geliştirilmesi, motivasyonun sağlanması, elde tutulması için yerine getirilen tüm faaliyetlerin yönetimi (Barutçugil, 2004: 32) ve çalı̧̧anların örgüte, kendine, çevreye fayda sağlayacak bir biçimde etken bir şekilde yönetilmesini sağlayan işlev ve çalışmaların tamamı olarak tanımlanmaktadır (Sadullah, 2015: 3). İKY, geleceği düşünerek örgütsel amaçlara ulaşmayı sağlayacak yetenekli ve motivasyonu yüksek kalifiye çalışan sağlamak, bu çalışanların iş tatminlerini arttırarak, yeteneklerinin ortaya çıkmasını sağlamak ve bu faaliyetleri gerçekleştirirken olabildiğince işgücü maliyetlerini de kontrol altında tutacak şekilde yapma görevini üstlenmektedir (Akın ve Erdost Çolak, 2012: 86). Bu bağlamda İKY görevini yerini getirirken çalışanların 
davranışlarını olumlu bir şekilde sergilemelerini sağlayacak, iş tatminlerini ve performanslarını arttıracak, işten ayrılma niyetlerini azaltacak şekilde planlama yapmaları gerekmektedir.

Örgüt içerinde çalışanların iş tatminlerini, motivasyonlarını, performanslarını olumsuz etkileyebilecek ve yeteneklerini sergilemesine engel teşkil edebilecek davranış çalışanın iş yaşamında yalnızlık duygusuna kapılması olarak ifade edilebilir. Ernst ve Cacioppo (1999: 1) yalnızlığı, bireylerin samimi ilişkiler ve sosyal ihtiyaçların yoksunluğuna karşı gösterdiği güçlü bir duygu olarak tanımlamaktadır. Başka bir ifadeyle yalnızlık, bireyin ait olma, başkaları tarafından kabul görülerek, onay alma, başkalarıyla iletişim kurma, sosyalleşme gibi psiko sosyal ihtiyaçlarının gereken miktarda karşılanmaması sonucunda bireyin kendini ötekileştirme ve diğerlerinden soyutlama şeklinde yaşadığı içsel bir deneyim olarak tanımlanmaktadır (Yakut ve Certel, 2016: 72). İş yaşamında yalnızlık (IYY), sadece iş ortamında etkin olabilen iş dışında oldukça tatmin edici ve sağlıklı ilişkileri olan ve yalnızlık duygularına sahip olmayan bir birey, iş ortamında sosyal ilişki kurma ve destek alma noktasında sorunlar yaşayabilmekte ve bireyin IYYY duyguları yaşamasına sebep olabilmektedir (Doğan vd., 2009: 272). IYYY duygusuna sahip çalışanların stres düzeyleri yüksek olabilmektedir. Bu durum çalışanın verimliliğini önemli ölçüde azaltabilmekte, agresif, içe kapanık, benlik olgusu düşük, kendine güvensiz bir profil sergilemesine ve iş arkadaşlarıyla olan ilişkilerinin kötüleşmesine sebep olabilmektedir (Keser ve Karaduman, 2014: 181) . IKKY uygulamalarının etkinliği örgüt içerisinde çalışanların iş yaşamında yalnızlıklarını da önemli ölçüde olumlu olarak etkileyebilecektir. Bu nedenle araştırmada temel amaç IKKY uygulamaları ile IYYY arasındaki ilişkinin belirlenerek iş yaşamında yalnızlığa yönelten örgütsel etkenlerin neler olabileceğinin belirlenmesi ve bunlara çözüm önerileri getirilmesidir.

\section{Kavramsal Çerçeve}

\section{İnsan Kaynakları Yönetimi}

Günümüz dünyasında meydana gelen değişim süreciyle birlikte iş yaşamı da hızlı ve güçlü olarak etkilenmektedir. Bu değişim süreci içinde yer edinebilme, rekabet edebilme ve üstünlük sağlayabilme noktasında işletmeler insan kaynakları yönetim anlayışına yönelmektedir. İnsan kaynakları kavramı, örgütte mevcut işgücüyle birlikte örgüt dışında fayda sağlanabilecek potansiyel işgücünü de kapsamaktadır. İnsan kaynakları, insan üretim faktörünü yatırım yapılabilecek en önemli kaynak olarak değerlendiren, teknolojiyi ve bilgiyi kullanabilen ve yaratıcılık noktasında kendini sürekli geliştiren kalifiye işgücünün yaygınlaşmasını amaçlayan bir yönetim anlayışı olarak ifade edilmektedir (Güler, 2006: 17). Başka bir ifadeyle; İKY örgütlerde çalışanların istihdamı, gelişimi ve refahına yönelik stratejik, bütünleşik ve tutarlı bir yaklaşım olarak tanımlanabilir (Armstrong, 2010: 8). İnsan kaynakları yönetiminin odak noktası, etkin işgücünü örgüte çekerek, onları geliştirmek ve bunun etkin bir şekilde sürdürülebilirliğini sağlamaktır (Calp, 2016: 549). İKY uygulamaları, insanların örgütlerde nasıl çalıştığı ve yönetildiği ile ilgili olup, stratejik İKY, beşeri sermaye yönetimi, bilgi yönetimi, organizasyon gelişimi, insan kaynakları planlaması, işe alım ve seçim, yetenek yönetimi, performans yönetimi, öğrenme ve geliştirmek, ödül yönetimi, çalışan ilişkileri ve refahı gibi faaliyetleri kapsamaktadır (Armstrong, 2010: 8). Bu çalışmada İKY uygulamaları, ödüllendirme, ücret sistemi, eğitim uygulamaları ve performans değerlendirme, iş gören ile iletişim ve kariyer sistemi olarak incelenmektedir.

Ödüllendirme: İKY uygulamalarında ödüllendirme, çalışanı örgütün verimlilik, yenilikçilik ve kârlılık hedeflerine ulaşmaya motive etmek için kullanılmaktadır (Mahapatro, 2010: 13). Ödüllendirme, çalışanlara yaptıkları iş için parasal değer sağlama süreci olarak ifade edilmekte ve kalifiye çalışanları işe almak, performansı ödüllendirmek, maliyetleri azaltmak üzere örgüt sadakatini teşvik etmek için kullanılabilir. Ödüllendirme; fazla mesai, ikramiye, seyahat/konaklama ödeneği, hisse senedi seçenekleri, sağlı ödeneği veya kar paylaşımını içerebilir (Hassan, 2016: 16). Frye (2004: 52) tarafından yapılan çalışmada, ödüllendirme ve örgütün performansı arasında pozitif yönde bir ilişki olduğunu ve ödüllendirme stratejilerinin kalifiye çalışanları işe alma ve elde tutmada önemli bir rol oynadığını ifade etmektedir. 
Ücret sistemi: Ücret, çalışanın işi için aldığı her şeyi içermektedir. Ancak örgüt, ücret sisteminin adil olduğunu, sektör standartlarını karşıladığını ve çalışanları kuruluş için çalışmaya ikna edecek düzeyde olduğunu belirlemelidir. Bununla birlikte ücret sistemi, benzer işleri yapan diğer kişilere ödenen ücretle karşılaştırılabilir olmasını sağlamalı ve çalışanın örgütteki yıl sayısını, deneyim yıllarını, eğitimi ve benzer yönleri dikkate alan ödeme sistemlerinin kurulmasını içermektedir (Frasch vd., 2009: 4). Örgüt açısından ücret sistemi; yasal, ekonomik ve çevresel taleplere uygun olarak rekabetçi olmasını sağlayacak bir ücret yönetim sisteminin kurulması ve uygulanması kapsamında nasıl bir politika izleneceğine dair temel karar ve planları kapsamaktadır (Ataay ve Acar, 2015: 371).

Eğitim uygulamaları ve performans değerlendirme: İKY uygulamalarında eğitim, çalışanlara işlerini yapmak üzere ihtiyaç duydukları becerileri kazandırmak üzere kullanılan yöntemler olarak tanımlanmaktadır. Bu nedenle, eğitim bir çalışanı belirli becerilere hazırlamayı gerektirmekte ve kişisel odaklı olmaktan ziyade iş için olmaktadır. Eğitim genellikle bilgi, beceri veya tutumlardaki zayıflıkları ele alarak işyerinde performansta bir iyileşme sağlamayı amaçlamaktadır (Itika, 2011: 128). Performans değerlendirme sisteminde örgütler değerlendirme mekanizmalarını kullanarak çalışanın istenen tutum ve davranışlarının gelişimini izleyebilmektedir. Söz konusu değerlendirmeye dayalı bilgiler, istenen davranış ve tutumlara sahip çalışanları seçmek ve geliştirmek üzere seçim ve eğitim uygulamalarını değiştirmek için kullanılabilmektedir. Ancak, çalışanlar işlerini yapmaya motive olmadıkları sürece sistemin etkinliği sınırlı kalabilecektir (Singh, 2004: 304).

İş gören ile İletişim: İKY uygulamalarında iş gören ile iletişim doğrudan veya dolaylı olarak çalışanlar ve yöneticiler arasındaki ilişkiyi içermektedir. Örgütün örgütsel hedeflere ve çalışanların hedeflerine ulaşması için bu ilişkiyi etkili bir şekilde yönetmeye ihtiyaç duyulmaktadır. Bu bağlamda çalışanların hakları göz önünde bulundurularak hem yöneticilerle hem de çalışanlarla görev tanımlarıyla iletişim kurmak esasıyla stratejiler geliştirmek gerekmektedir (Osibanjo ve Adeniji, 2012: 13). Bununla birlikte örgütte çalışanların katılımı, çalışanların kararlarını alma ve işleri ile ilgili eylemlerde bulunma yetkisine sahip oldukları bir ortam yaratmakta, örgüte bağlılığı arttırarak, çalışanları motive etmekte ve çalışanların örgütsel faaliyetlere katkıda bulunmasını sağlamaktadır. Çalışanları karar alma süreçlerine dâhil ederek güçlendirmek, verimliliği arttırdığı, karar verme süresinden tasarruf sağladığı, denetim otoritesi ve astları arasındaki boşluğu azalttığı için örgütün başarısına katkıda bulunarak, çalışanlar arasında güçlü bir ekip çalışmasını teşvik etmektedir (Hassan, 2016: 17).

Kariyer Sistemi: Kariyer yönetimi, çalışanların değerler, ilgi alanları ve becerileri, güçlü ve zayıf yönleri hakkında bilgi toplama, kariyer hedefini belirleme ve kariyer hedeflerine ulaşma olasılığını artıran kariyer stratejileri oluşturma sürecidir. Bu süreç, kariyer keşfi, kariyer hedeflerinin geliştirilmesi ve kariyer hedeflerine ulaşmak için kariyer stratejilerinin kullanılmasını içermektedir (Patrick ve Kumar, 2011: 25). Kariyer gelişimi ise, çalışanın kariyer ihtiyaçlarını ve örgütün işgücü gereksinimlerini dengelemek için organize, resmileşmiş, planlanmış bir çaba olarak tanımlanmakta ve çalışanları kariyer zenginleştirmeye yönlendirmek, örgütün amacına ulaşmak için İKY uygulamalarının önemli bir yönü olarak kabul edilmektedir (Leibowitz vd., 1986; Nadler ve Nadler, 1989; akt. Dawwas ve Zahare, 2014: 12). Örgütte kariyer sistemi çalışanın bilgi, beceri ve yeteneklerini geliştirmek için çalıştığı örgütün ortak ve sürekli bir çabası olmakla birlikte çalışanın kariyer ihtiyaçları ve hedefleri ile örgütün iş yapma ihtiyacı arasında bir denge kurulmasını gerektirmektedir. Bu sayede çalışan gelişim programları örgütsel performansa olumlu katkılarda bulunabilmekte ve çalışanlar deneyim ve bilgi kazandıkça daha fazlasını başarabilmektedir (Patrick ve Kumar, 2011: 26).

Örgütlerde İKY uygulamaları ile ilgili çalışmalara göre İKY uygulamaları çalışanların örgütsel bağlılığını (Paşaoğlu, 2015; Ocen vd., 2017; Coffie vd., 2018; Yeşil ve Özel, 2019), performasını (Erdil vd., 2004; Çalışkan, 2010; Özutku ve Çetinkaya, 2012; Türen vd., 2013; 
Soran vd., 2016) ve motivasyonunu (Jiang vd., 2012) olumlu olarak işe yabancılaşmasını (Güler vd., 2018), işten ayrilma niyetlerini (Guchait ve Cho, 2010; Long ve Perumal, 2014; Boz, 2019) olumsuz olarak etkilemektedir.

\section{İş Yaşamında Yalnızlık}

Yalnızlık, birey yaşantısının her alanında görülebildiği gibi iş yaşamında da kendini gösterebilmekte ve çalışanı olumsuz olarak etkileyebilmektedir (Demirbaş ve Haşit, 2016: 137). Örgütlerde, kişilerarası sağlıklı ilişkilerin teşvik edilmesi, örgütlerin ayrılmaz bir parçası olmakta ve çoğu durumda çalışanların başka bir örgütte bulamayacağı arkadaşlıklar sağlamaktadır (Wright vd., 2006: 59). Yalnızlık kelime anlamı olarak, yalnız olma durumu veya kimsesizlik olarak ifade edilmektedir (Türk Dil Kurumu, 2020). İYY, örgütte çalışan kişinin diğer çalışanlar arasında kendisini yalnız hissetmesi anlamına gelmektedir. Başka bir ifadeyle; çalışanın diğer çalışanlarla sosyal ilişkiler geliştirememesini, kendisini onlarla birlikte hissedememesini, tek başına kaldığını hissetmesidir (Koçel, 2014: 531). IYY, bir çalışma ortamında kaliteli kişilerarası ilişkilerin eksikliğinin algılanmasından kaynaklanan sıkıntı olarak kendini gösteren, bireyin algısına dayanan ve genellikle sosyal destek eksikliğine işaret eden bir kavramdır (Wright vd., 2006: 59-60). IYYY hisseden çalışan ekip çalışmasına katılamayan, motivasyonunu kaybeden ve gittikçe örgüte yabanc1lık hisseden ve verimsiz bir çalışan haline gelebilmektedir (Koçel, 2014: 531).

IYY; Wright vd. (2006) tarafından sosyal arkadaşlık (yalnızlık) ve duygusal yalnızlık olarak iki boyutta incelenmektedir.

Sosyal arkadaşlık: Sosyal yalnızlık olarak da ifade edilen sosyal arkadaşlık çalışanlar arasında sosyal ilişkiler ya da çalışanın kendini kabul ettireceği bir örgüt içinde bulunmaması ve buna bağlı olarak çekingenlik, diğer çalışanlar tarafından reddedilme hissine kapılmasıdır. Çalışanlar söz konusu duygulardan sosyal ilişkiler içine girdiklerinde kurtulabilmektedirler. Bununla birlikte Weis (1973), Vincenzi ve Grabosky (1987)'e göre bağlanma, sosyal olarak bütünleşme, takdir görme, güvenilir dostluklar, himaye ve rehberlik ilişkilerinden birinin yokluğu, sosyal yalnızlığın kaynağı olabilmektedir (Şişman ve Turan, 2004: 120). Sosyal yalnızlıktan muzdarip bir çalışan, sosyal bir gruba ait olma hissinden yoksundur ve gerçekten gruba ait olup olmadığından şüphe ederek, diğer çalışanlarla ilişki kurma yeteneklerini sorgulamaktadır (Wright, 2005: 24).

Duygusal yalnızlık: Duygusal yalnızlık, yakın bir ilişkinin olmamasından kaynaklanır ve birebir ilişkilerle ilgilidir. Duygusal yalnızlık, bireylerle yakın bağlanma ilişkileri eğilimindedir. Birey duygusal olarak yalnız olduğunda, genel bir üzüntü ve boşluk hissine kapılmakta ve başkalarıyla yakın ilişkiler kurma arzusu yaşamaktadır. (Wright, 2005: 24). Duygusal yalnızlık, yakın ilişkiler tarafından sağlanan duygusal bağlılıkların yokluğundan kaynaklanmaktadır. Yas, boşanma veya mutsuz evlilikler duygusal yalnızlığın öncüllerindendir. Anksiyete, mutlak bir yalnızlık duygusu, tehditlere karşı için uyanıklık ve başkalarının düşmanca veya sevecen davranışlarını yanlış yorumlama eğilimi duygusal yalnızlığın belirtileri arasında sayılabilir (Perlman ve Peplau, 1998: 574).

IYYY ile ilgili çalışmalara göre İYY, çalışanların işten ayrılma niyetlerini (Ertosun ve Erdil, 2012; Demirbaş ve Haşit, 2016; Erdirençelebi ve Ertürk, 2018), sosyal fobilerini (Mercan ve diğerleri, 2012) tetiklemekte ve örgütsel vatandaşlık davranışlarını (Keser ve Karaduman, 2014), örgütsel bağlllıklarını (Ertosun ve Erdil, 2012), iş tatminlerini (Erdirençelebi ve Ertürk, 2018), iş performanslarını (Deniz, 2019), örgütsel sosyalleşmelerini (Çavuş ve Biçer, 2019) olumsuz olarak etkilemektedir.

Otel işletmelerinin sağlıklı işleyişi, verimliliği ve sürekliliği istihdam edilen çalışanlara göre şekillenmektedir. Çünkü çalışanlar örgüt içinde bulundukları duruma göre işletmeye ve çalışma arkadaşlarına karşı bir tutum geliştirmekte ve söz konusu tutumların olumsuz düzeyde 
gerçekleşmemesi adına özellikle otel işletmelerinde insan kaynaklarının etkin ve olumlu bir şekilde yönetilmesi gerekmektedir.

İKY uygulamalarının etkinliği çalışanların örgütsel aidiyet duygusunu, performansını, vatandaşlık davranışını, iş tatminini, örgüte karşı güvenini arttırabileceği gibi örgütün verimliliğini ve imajını olumlu olarak arttırabilecektir. Bu sayede çalışanlar verimli çalışarak, kendilerini geliştirerek kendilerine verilen görevlerden daha fazlasını yaparak, örgütün misyonu ve vizyonu uyumlu hale gelebilecek ve örgütün başarıyla amaçlarına ulaşmasını sağlayabileceklerdir.

İKY uygulamaları çalışanların iş yaşamında kendilerini yalnız hissetmelerini de tetikleyebilmektedir. IYY, çalışanın örgüte karşı aidiyet duygusunu azaltabilmekte, örgütün imajına, gelişmesine ve amaçlarına ulaşmasına katkı sağlayacak faaliyetlerden kaçınabilmekte, öfkeli ve gergin olabilmektedir. Bu durum örgüte ve yönetime karşı güveni azaltarak, çalışanın motivasyonunu düşürmekte ve çalışanı niteliksel ve psikolojik olarak olumsuz etkileyebilmektedir. Buna bağlı olarak söz konusu durum otel işletmelerinde çalışanla doğrudan iletişim içerisinde olan otel müsşterilerine de yansıyabilecek ve müşteri memnuniyetini azaltabilecektir. Bu bağlamda ilgili literatür çalışmalarından yola çıkılarak İKY uygulamalarının İYY'yi tetikleyeceği varsayımıyla ve yerli ve yabancı literatürde otel işletmelerinde IKY ve IYYY arasındaki ilişkiyi konu alan bir çalışma bulunmadığından dolayı bu araştırmada temel amaç otel işletmelerinde İKY uygulamaları ile İYY arasındaki ilişkinin belirlenmesidir. Ayrıca İKY uygulamalarının ve IYYY'nin demografik faktörler açısından farklılaşmalarına bakılması da amaçlanmıştır. Bu temel amaç doğrultusunda araştırmanın hipotezleri ise şu şekilde oluşturulmuştur:

H1: İKY ile IYYY arasında negatif yönde anlamlı bir ilişki vardır.

H2: İKY uygulamalarının ödüllendirme boyutu ile IYY boyutlarından (a) sosyal arkadaşlık ve (b) duygusal yalnızlık arasında negatif yönde anlamlı bir ilişki vardır.

H3: İKY uygulamalarının ücret sistemi boyutu ile IYY boyutlarından (a) sosyal arkadaşlık ve (b) duygusal yalnızlık arasında negatif yönde anlamlı bir ilişki vardır.

H4: İKY uygulamalarının eğitim uygulamaları ve performans değerlendirme boyutu ile IYY boyutlarından (a) sosyal arkadaşlık ve (b) duygusal yalnızlık arasında negatif yönde anlamlı bir ilişki vardır.

H5: İKY uygulamalarının işgören ile iletişim boyutu ile IYYY boyutlarından (a) sosyal arkadaşlık ve (b) duygusal yalnızlık arasında negatif yönde anlamlı bir ilişki vardır.

H6: İKY uygulamalarının kariyer sistemi boyutu ile IYYY boyutlarından (a) sosyal arkadaşlık ve (b) duygusal yalnızlık arasında negatif yönde anlamlı bir ilişki vardır.

H7: Cinsiyet değişkenine göre (a) İKY ve (b) İYY farklılaşmaktadır.

H8: Medeni durum değişkenine göre (a) İKY ve (b) IYYY farklılaşmaktadır.

H9: Yaş değişkenine göre (a) İKY ve (b) İYY farklılaşmaktadır.

H10: Eğitim durumu değişkenine göre (a) İKY ve (b) IYYY farklılaşmaktadır.

H11: Turizm sektöründe çalışma süresi değişkenine göre (a) IKKY ve (b) İYY farklılaşmaktadır.

H12: İşletmede çalışma süresi değişkenine göre (a) İKY ve (b) IYYY farklılaşmaktadır.

\section{Yöntem}

Bu araştırmada otel işletmelerinde İKY uygulamaları ile çalışanların IYYY arasındaki ilişkinin belirlenmesi amaçlanmıştır. Bu amaç çerçevesinde basit tesadüfî örneklem yöntemi kullanılarak Türkiye'de farklı illerde otel işletmelerinde istihdam edilen 310 çalışana veri toplama yöntemi olan anket aracılığıyla ulaşılmıştır. Araştırmanın anket formu üç bölümden oluşmaktadır. Birinci bölüm, katılımcıların demografik özelliklerinin belirlenmesine yönelik cinsiyet, medeni durum, yaş, eğitim durumu, turizm sektöründe çalışma süresi ve işletmede çalışma süresi gibi sorulardan oluşmaktadır. Anketin ikinci bölümünde, İKY uygulamalarının düzeyini belirlemeye yönelik, Gürbüz ve Bekmezci'nin (2012) literatürden derleyerek geliştirmiş olduğu yirmi iki maddeden oluşan İnsan Kaynakları Yönetimi Uygulamaları Ölçeği kullanılmıştır. Gürbüz ve Bekmezci (2012) geliştirmiş oldukları İKY uygulamaları ölçeğinin geçerlilik ve güvenilirliğini test 
ederek, 5 boyut belirlemiştir. İKY uygulamaları ölçeğinin birinci boyutu ödüllendirme 5 , ikinci boyutu ücret sistemi 4 , üçüncü boyutu eğitim uygulamaları ve performans değerlendirme 5 , dördüncü boyutu işgören ile iletişim 5 ve beşinci boyutu ise kariyer sistemi 3 olmak üzere toplam 22 yargıdan oluşmakta ve bu araştırmada cronbach's alpha katsayıları sırasıyla $\alpha$ 0,953-0,9330,921-0,922 ve 0,834 olarak belirlenmiştir. Anketin üçüncü bölümünde, katılımcıların IYYY durumlarını belirlemeye yönelik, Wright vd.,'nin (2006) tarafindan geliştirilmiş olan ve ölçeğin Türkçe geçerlilik ve güvenilirlik çalışmasının Doğan vd. (2009) tarafından yapılan 16 maddeden oluşan İş Yaşamında Yalnızlık Ölçeği kullanılmıştır. Wright vd. (2006) geliştirmiş oldukları IYYY ölçeğinin geçerlilik ve güvenilirliğini test ederek, 2 boyut belirlemiştir. İYY ölçeğinin birinci boyutu sosyal arkadaşlık 7, ikinci boyut ise duygusal yoksunluk 9 yargıdan oluşmakta ve bu araştırmada cronbach's alpha katsayıları sırasıyla 0,951 ve 0,897 olarak belirlenmiştir. Söz konusu ölçeklerde 5' li Likert esas alınarak 1 Kesinlikle Katılmıyorumdan 5 Kesinlikle Katılıyoruma kadar derecelendirme yapılmıştır. Araştırmada veri toplama yöntemi olan anket aracılığıyla elde edilen veriler istatistik programı aracılığıyla analize tabi tutulmuştur. Araştırmada otel işletmelerinde İKY uygulamaları ile çalışanların IYYY'leri arasındaki ilişkiyi belirlemeye yönelik korelasyon analizi yapılarak demografik özelliklere göre katılımcıların İKY uygulamaları ile çalışanların IYYY farklılaşmasını belirlemeye yönelik analizler yapılmıştır.

\section{Bulgular}

Otel işletmelerinde İKY uygulamaları ile çalışanların IYYY'leri arasındaki ilişkinin belirlenmesine yönelik yapılan bu araştırmada öncelikle araştırmanın örneklem profili belirlenmiştir. Araştırmada İKY ile IYYY arasındaki ilişkiyi belirlemeye yönelik korelasyon, araştırmanın değişkenlerinin birbirine etkisini belirlemek amacıyla regresyon analizi, katılımcıların demografik özelliklerine göre İKY uygulamaları ile IYY farklılaşmasına $t$ testi ve ANOVA analizleri yapılmıştır.

Tablo 1: Araştırmanın Örneklem Profili

\begin{tabular}{|c|c|c|c|c|c|c|c|}
\hline Değişkenler & & f & $\%$ & Değişkenler & & f & $\%$ \\
\hline \multirow{2}{*}{ Cinsiyet } & Erkek & 175 & 56,5 & Medeni & Evli & 170 & 54,8 \\
\hline & Kadın & 135 & 43,5 & Durum & Bekâr & 140 & 43,5 \\
\hline \multirow{4}{*}{ Yaş } & 20 yaş ve altı & 55 & 17,7 & \multirow{4}{*}{$\begin{array}{l}\text { Eğitim } \\
\text { Durumu }\end{array}$} & İlköğretim & 45 & 14,5 \\
\hline & $21-30$ yaş & 40 & 12,9 & & Lise & 125 & 40,3 \\
\hline & $31-40$ yaş & 80 & 25,8 & & Ön lisans & 120 & 38,7 \\
\hline & $41-50$ yaş & 135 & 43,5 & & Lisans & 20 & 6,5 \\
\hline & $0-1$ yıl arasinda & 10 & 3,20 & \multirow{6}{*}{$\begin{array}{l}\text { İşletmede } \\
\text { Çalış̧ma } \\
\text { Süresi }\end{array}$} & $0-1$ yil arasinda & 65 & 21,0 \\
\hline Turizm & 2-3 yıl arasinda & 45 & 14,5 & & 2-3 yıl arasinda & 135 & 43,5 \\
\hline Sektöründe & 4-5 yıl arasinda & 85 & 27,4 & & 4-5 yıl arasinda & 55 & 17,7 \\
\hline Çalışma & 6-7 yıl arasinda & 30 & 9,7 & & 6-7 yıl arasinda & 15 & 4,8 \\
\hline \multirow[t]{2}{*}{ Süresi } & 8-9 yıl arasinda & 40 & 12,9 & & 8-9 yıl arasinda & 10 & 3,2 \\
\hline & 10 yıl ve üzeri & 100 & 32,3 & & 10 yıl ve üzeri & 30 & 9,7 \\
\hline TOPLAM & & 310 & 100 & TOPLAM & & 310 & 100 \\
\hline
\end{tabular}

Araştırmanın örneklem profilini oluşturan çalışanların büyük bir çoğunluğu erkek $(\% 56,5)$, evli $(\% 54,8), 41-50$ yaş arasında $(\% 43,5)$ ve lise mezunu $(\% 40,3)$ katılımcılardan oluşmaktadır. Katılımcıların turizm sektöründe çalışma sürelerine göre en çok \%32,3 oranla 10 y1l üzeri ve işletmede çalışma sürelerine göre en çok \%43,5 bir oranla 2-3 yıl arasındaki çalışanlardan oluşmaktadır. 
Tablo 2: İnsan Kaynakları Yönetimi Uygulamaları İle İş Yaşamında Yalnızlık Arasındaki İlişkiyi Belirlemeye Yönelik Korelasyon Analizi

\begin{tabular}{l|ccc}
\hline & \multicolumn{3}{|c}{ BAĞIMLI DEĞIŞKENLER } \\
\cline { 2 - 4 } BAĞIMSIZ DEĞİŞKENLER & $\begin{array}{c}\text { İs Yaşamında } \\
\text { Yalnızlık }\end{array}$ & $\begin{array}{c}\text { Sosyal } \\
\text { Arkadaşlık }\end{array}$ & $\begin{array}{c}\text { Duygusal } \\
\text { Yoksunluk }\end{array}$ \\
\hline İnsan Kaynakları Yönetimi Uygulamaları & $-0,862$ & $-0,705$ & $-0,830$ \\
Ödüllendirme & $-0,656$ & $-0,740$ & $-0,053$ \\
Ücret Sistemi & $-0,813$ & $-0,772$ & $-0,045$ \\
Ĕgitim Uyg. ve Performans Değerlendirme & $-0,724$ & $-0,747$ & $-0,127$ \\
İşgören ile İletişim & $-0,499$ & $-0,837$ & $-0,130$ \\
Kariyer Sistemi & $-0,631$ & $-0,814$ & $-0,090$ \\
\hline
\end{tabular}

Tablo 2'te yapılan korelasyon analizinin sonucuna göre, korelasyon katsayıları -1'e yakın olduğunda değişkenler arasında negatif bir ilişki bulunmaktadır. Bu bağlamda otel işletmelerinde IKY uygulamaları ile IYYY ( $\mathrm{r}=-0,862)$, IYY boyutlarından sosyal arkadaşlık $(\mathrm{r}=-0,705)$, duygusal yoksunluk $(r=-0,830)$ arasında anlamlı düzeyde negatif yönlü yüksek bir ilişki olduğu tespit edilmiştir. Bu kapsamda İKY uygulamalarının etkinliği arttıkça çalışanların IYYY, sosyal arkadaşlık ve duygusal yoksunluk düzeylerinin azalacağını söylemek mümkündür. Bu sonuca göre İKY ile IYY arasında negatif yönde bir ilişki vardır H1 hipotezi kabul edilmektedir. Bununla birlikte İKY uygulamaları boyutlarından ödüllendirme ile IYY $(\mathrm{r}=-0,656)$ arasında orta düzeyde, IYY boyutlarından sosyal arkadaşlık $(\mathrm{r}=-0,740)$ arasında yüksek düzeyde, duygusal yoksunluk $(\mathrm{r}=-$ 0,053 ) arasında çok zayıf anlamlı düzeyde negatif yönlü bir ilişki olduğu belirlenmiştir. Bu bulguya göre, İKY uygulamaları boyutlarından ödüllendirme arttıkça çalışanların IYY, sosyal arkadaşlık ve duygusal yoksunluk düzeyleri azalma gösterebilecektir. Bu sonuca göre $\mathrm{H} 2 \mathrm{a}$ ve $\mathrm{H} 2 \mathrm{~b}$ hipotezleri kabul edilmektedir. İKY uygulamaları boyutlarından ücret sistemi ile IYYY (r=-0,813), IYYY boyutlarından sosyal arkadaşlık $(\mathrm{r}=-0,772)$ arasında yüksek düzeyde, duygusal yoksunluk $(\mathrm{r}=-$ $0,045)$ arasında çok zayıf anlamlı düzeyde negatif yönlü bir ilişki olduğu belirlenmiştir. $\mathrm{Bu}$ bağlamda, İKY uygulamaları boyutlarından ücret sistemi etkinliği arttıkça çalışanların IYYY, sosyal arkadaşlık ve duygusal yoksunluk düzeyleri azalabilecektir. H3a ve H3b hipotezleri kabul edilmektedir. İKY uygulamaları boyutlarından eğitim uygulamaları ve performans değerlendirme ile IYY ( $\mathrm{r}=-0,724)$, IYY boyutlarından sosyal arkadaşlık $(\mathrm{r}=-0,747)$ arasında yüksek düzeyde, duygusal yoksunluk $(\mathrm{r}=-0,127)$ arasında çok zayıf anlamlı düzeyde negatif yönlü bir ilişki olduğu belirlenmiştir. Bu bağlamda, İKY uygulamaları boyutlarından eğitim uygulamaları ve performans değerlendirme etkinliği arttıkça çalışanların IYY, sosyal arkadaşlık ve duygusal yoksunluk düzeyleri azalabilecektir. $\mathrm{Bu}$ sonuca göre $\mathrm{H} 4 \mathrm{a}$ ve $\mathrm{H} 4 \mathrm{~b}$ hipotezleri kabul edilmektedir. İKY uygulamaları boyutlarından iş gören ile iletişimle IYYY $(\mathrm{r}=-0,499)$ arasında zayıf düzeyde, IYY boyutlarından sosyal arkadaşlık $(\mathrm{r}=-0,837)$ arasında yüksek düzeyde, duygusal yoksunluk $(\mathrm{r}=-$ 0,130 ) arasında çok zayıf anlamlı düzeyde negatif yönlü bir ilişki olduğu belirlenmiştir. Bu bulguya göre, IKY uygulamaları boyutlarından iş gören ile iletişim arttıkça çalışanların IYY, sosyal arkadaşl1k ve duygusal yoksunluk düzeyleri azalma gösterebilecektir. Bu sonuca göre H5a ve H5b hipotezleri kabul edilmektedir. İKY uygulamaları boyutlarından kariyer sistemi ile İYY $(\mathrm{r}=-0,631)$ arasında orta düzeyde, IYYY boyutlarından sosyal arkadaşlık $(\mathrm{r}=-0,814)$ arasında yüksek düzeyde, duygusal yoksunluk $(\mathrm{r}=-0,090)$ arasında çok zayıf anlamlı düzeyde negatif yönlü bir ilişki olduğu belirlenmiştir. Bu bağlamda, İKY uygulamaları boyutlarından kariyer sistemi etkinliği arttıkça çalışanların IYY, sosyal arkadaşl1k ve duygusal yoksunluk düzeyleri azalabilecektir. Bu sonuca göre H6a ve H6b hipotezleri kabul edilmektedir.

Tablo 2'deki korelasyon analizi sonucuna göre otel işletmelerinde IKKY uygulamalarında ödül sisteminin nitelikli personeli motive edecek şekilde olması, çalışanın harcadığı çabanın tam karşılığ1 olan bir ücret alması, performans değerlendirme sisteminin yüksek nitelikli personeli doğru ayırt edebilecek şekilde olması, otelde yönetim kademeleri arasındaki iletişim kalitesinin yüksek olması ve işini iyi yapan çalışanın adil bir şekilde terfi ettirilmesine bağlı olarak çalışanlar 
iş ortamında baskı altındayken iş arkadaşları tarafından yalnız bırakıldığını, kendilerini çalışma arkadaşlarından duygusal olarak uzak hissetmeyebilecek, oteldeki ilişkilerinden memnuniyet duyabilecek, sosyal etkinliklere (piknik, parti, yemek gibi) katılım gösterebilecek ve kendini oteldeki arkadaş grubunun bir parçası olduğunu düşünerek otelde kişisel düşüncelerini paylaşabilecektir.

Tablo 3: İnsan Kaynakları Yönetimi Uygulamalarının İş Yaşamında Yalnızlık Üzerine Etkisini Belirlemeye Yönelik Regresyon Analizi

\begin{tabular}{|c|c|c|c|c|c|c|}
\hline & \multicolumn{6}{|c|}{ BAĞIMLI DEĞİŞKENLER } \\
\hline & \multicolumn{2}{|c|}{$\begin{array}{l}\text { İş Yaşamında } \\
\text { Yalnızlık }\end{array}$} & \multicolumn{2}{|c|}{$\begin{array}{c}\text { Sosyal } \\
\text { Arkadaşlık }\end{array}$} & \multicolumn{2}{|c|}{$\begin{array}{c}\text { Duygusal } \\
\text { Yoksunluk }\end{array}$} \\
\hline $\mathbf{R}^{2}$ & \multicolumn{2}{|c|}{$\mathbf{0 , 8 2 2}$} & \multicolumn{2}{|c|}{0,740} & \multicolumn{2}{|c|}{0,759} \\
\hline BAĞIMSIZ DEĞİŞKENLER & Beta & p & Beta & p & Beta & p \\
\hline İnsan Kaynakları Yönetimi Uyg. & $-0,862$ & $\mathbf{0 , 0 0 0}$ & $-0,705$ & 0,000 & $-0,830$ & 0,000 \\
\hline Ödüllendirme & $-0,785$ & $\mathbf{0 , 0 0 0}$ & $-0,656$ & $\mathbf{0 , 0 0 0}$ & $-0,740$ & $\mathbf{0 , 0 0 0}$ \\
\hline Ücret Sistemi & $-0,898$ & $\mathbf{0 , 0 0 0}$ & $-0,813$ & $\mathbf{0 , 0 0 0}$ & $-0,772$ & 0,000 \\
\hline Eğitim Uyg. ve Performans Değ. & $-0,831$ & $\mathbf{0 , 0 0 0}$ & $-0,724$ & $\mathbf{0 , 0 0 0}$ & $-0,747$ & $\mathbf{0 , 0 0 0}$ \\
\hline İşgören ile İletişim & $-0,740$ & $\mathbf{0 , 0 0 0}$ & $-0,499$ & $\mathbf{0 , 0 0 0}$ & $-0,837$ & $\mathbf{0 , 0 0 0}$ \\
\hline Kariyer Sistemi & $-0,808$ & $\mathbf{0 , 0 0 0}$ & $-0,631$ & $\mathbf{0 , 0 0 0}$ & $-0,814$ & $\mathbf{0 , 0 0 0}$ \\
\hline
\end{tabular}

Tablo 3'teki regresyon analizi sonuçlarına göre $\mathrm{R}^{2}$ determinasyon katsayısı değerine göre, IYYY bağımlı değişkenin \%82'si $\left(\mathrm{R}^{2}=0,822\right)$ IKKY uygulamaları tarafından açıklanabilmektedir. Bunun yanı sıra anlamlılık (p) değerlerine göre bağımlı ve bağımsız değişkenler arasındaki tüm ilişkilerin anlamlı olduğu sonucuna ulaşılmıştır. Bununla birlikte İKY uygulamaları boyutlarından ödüllendirme, ücret sistemi, eğitim uygulamaları ve performans değerlendirme, iş gören ile iletişim ve kariyer sistemindeki bir birimlik artış otel işletmelerinde çalışanların iş yaşamında yalnızlığ üzerinde sırasıyla $-0,785,-0,898,-0,831,0,740$ ve $-0,808$ birimlik azalış sağlamaktadır. Bununla birlikte $\mathrm{R}^{2}$ determinasyon katsayısı değerine göre, İYY boyutlarından sosyal arkadaşlık bağımlı değişkenin \%74' $\ddot{u}\left(\mathrm{R}^{2}=0,740\right)$ İKY uygulamaları tarafından açıklanabilmektedir. Bununla birlikte İKY uygulamaları boyutlarından ödüllendirme, ücret sistemi, eğitim uygulamaları ve performans değerlendirme, işgören ile iletişim ve kariyer sistemindeki bir birimlik artış otel işletmelerinde çalışanların sosyal arkadaşlığ 1 üzerinde sırasıyla $-0,656,-0,813,0,724,-0,499$ ve $-0,631$ birimlik azalış sağlamaktadır. $\mathrm{R}^{2}$ determinasyon katsayısı değerine göre, IYY boyutlarından duygusal yoksunluk bağımlı değişkenin \%75'i $\left(\mathrm{R}^{2}=0,759\right)$ İKY uygulamaları tarafından açıklanabilmektedir. Bununla birlikte İKY uygulamaları boyutlarından ödüllendirme, ücret sistemi, eğitim uygulamaları ve performans değerlendirme, işgören ile iletişim ve kariyer sistemindeki bir birimlik artış otel işletmelerinde çalışanların duygusal yoksunluğu üzerinde sırasıyla $-0,740,-0,772,0,747,-0,837$ ve $-0,814$ birimlik azalış sağlamaktadır.

Tablo 4: Katılımcıların cinsiyet değişkenine göre insan kaynakları yönetimi uygulamaları ve iş yașamında yalnızlık farklılașması

\begin{tabular}{|c|c|c|c|c|c|c|}
\hline & & $\mathbf{F}$ & Ort. & S.s. & $\mathbf{F}$ & $\mathbf{p}$ \\
\hline \multirow{2}{*}{$\begin{array}{l}\text { İnsan Kaynakları Yönetimi } \\
\text { Uygulamaları }\end{array}$} & Erkek & 175 & 4,20 & 0,80 & \multirow{2}{*}{32,955} & \multirow{2}{*}{$\mathbf{0 , 0 0 0}$} \\
\hline & Kadın & 135 & 4,52 & 0,39 & & \\
\hline \multirow{2}{*}{ İş yaşamında Yalnızlık } & Erkek & 175 & 2,06 & 0,70 & \multirow{2}{*}{15,298} & \multirow{2}{*}{$\mathbf{0 , 0 0 1}$} \\
\hline & Kadın & 135 & 1,81 & 0,55 & & \\
\hline
\end{tabular}

Katılımcıların cinsiyet değişkenine göre İKY uygulamaları ve İYY farklılaşması bağımsız iki örnek $\mathrm{t}$ testi sonucuna göre $\mathrm{p}<0,05$ olduğundan anlamlı bir farklılık belirlenmiştir. Bu bağlamda İKY uygulamaları ve IYYY katılımcıların cinsiyetine göre bir farklılık göstermektedir. Bununla birlikte ortalamaya bakıldığında kadın katılımcılar erkek katılımcılara göre daha fazla İKY uygulamalarının olduğunu düşünmekte ve IYYY göstermemektedir (Tablo 4). Bu sonuçlara göre; H7a ve H7b hipotezleri kabul edilmektedir. 
Tablo 5: Katılımcıların medeni durum değişkenine göre insan kaynakları yönetimi uygulamaları ve iş yaşamında yalnızlık farklılaşması

\begin{tabular}{lllcccc}
\hline & & f & Ort. & s.s. & F & p \\
\hline İnsan Kaynakları Yönetimi & Evli & 170 & 4,43 & 0,68 & \multirow{2}{*}{6,890} & \multirow{2}{*}{$\mathbf{0 , 0 0 9}$} \\
\cline { 2 - 3 } & Bekâr & 140 & 4,23 & 0,65 & & \multirow{2}{*}{0,095} \\
\hline \multirow{2}{*}{ İş yaşamında Yalnızlık } & Evli & 170 & 1,89 & 0,71 & \multirow{2}{*}{50,024} & \multirow{2}{*}{$0,0,56$} \\
\hline
\end{tabular}

Katılımcıların medeni durum değişkenine göre İKY uygulamaları farklılaşması ve İYY bağımsız iki örnek $t$ testi sonucuna göre; İKY uygulamaları $p<0,05$ olduğundan anlamlı bir farklılık belirlenmiş, IYY $\mathrm{p}>0,05$ olduğundan anlamlı bir farklılık belirlenmemiştir. Bu bağlamda IKKY uygulamaları katılımcıların medeni durumuna göre bir farklılık göstermektedir. Bununla birlikte ortalamaya bakıldığında evli katılımcılar bekâr katılımcılara göre daha fazla İKY uygulamalarının olduğunu düşünmektedir (Tablo 5). Bu sonuçlara göre; H8a hipotezi kabul edilirken, H8b hipotezi ret edilmektedir.

Tablo 6: Katılımcıların yaş değişkenine göre insan kaynakları yönetimi uygulamaları ve iş yaşamında yalnızlık farklılaşması

\begin{tabular}{|c|c|c|c|c|c|c|}
\hline & & $\mathbf{f}$ & Ort. & S.S. & $\mathbf{F}$ & $\mathbf{p}$ \\
\hline \multirow{4}{*}{$\begin{array}{l}\text { İnsan Kaynakları Yönetimi } \\
\text { Uygulamaları }\end{array}$} & 20 yaş ve altı & 55 & 4,19 & 0,48 & \multirow{4}{*}{8,140} & \multirow{4}{*}{$\mathbf{0 , 0 0 0}$} \\
\hline & $21-30$ yaş & 40 & 4,08 & 1,11 & & \\
\hline & $31-40$ yaş & 80 & 4,24 & 0,26 & & \\
\hline & $41-50$ yaş & 135 & 4,54 & 0,68 & & \\
\hline \multirow{4}{*}{ İş yaşamında Yalnızlık } & 20 yaş ve altı & 55 & 2,15 & 0,61 & \multirow{4}{*}{10,070} & \multirow{4}{*}{0,000} \\
\hline & $21-30$ yaş & 40 & 1,91 & 0,71 & & \\
\hline & $31-40$ yaş & 80 & 2,17 & 0,46 & & \\
\hline & $41-50$ yaş & 135 & 1,75 & 0,69 & & \\
\hline
\end{tabular}

Katılımcıların yaş değişkenine göre İKY uygulamaları ve IYYY farklılaşması ANOVA testi sonucuna göre $\mathrm{p}<0,05$ olduğundan anlamlı bir farkl11ık belirlenmiştir. $\mathrm{Bu}$ bağlamda İKY uygulamaları ve IYY katılımcıların yaşına göre bir farklılık göstermektedir. Bununla birlikte ortalamaya bakıldığında 41-50 yaş arasındaki katılımcılar diğer yaş grubundaki katılımcılara göre daha fazla İKY uygulamalarının olduğunu düşünmekte ve İYY göstermektedir (Tablo 6). Bu sonuçlara göre; H9a ve H9b hipotezleri kabul edilmektedir.

Tablo 7: Katılımcıların eğitim durumu değişkenine göre insan kaynakları yönetimi uygulamaları ve iș yaşamında yalnızlık farklılașması

\begin{tabular}{|c|c|c|c|c|c|c|}
\hline & & f & Ort. & S.s. & $\mathbf{F}$ & p \\
\hline \multirow{4}{*}{$\begin{array}{l}\text { İnsan Kaynakları Yönetimi } \\
\text { Uygulamaları }\end{array}$} & İlköğretim & 45 & 4,38 & 0,76 & \multirow{4}{*}{2,324} & \multirow{4}{*}{0,075} \\
\hline & Lise & 125 & 4,44 & 0,63 & & \\
\hline & Ön lisans & 120 & 4,27 & 0,67 & & \\
\hline & Lisans & 20 & 4,10 & 0,65 & & \\
\hline \multirow{4}{*}{ İş yaşamında Yalnızlık } & İlköğretim & 45 & 1,73 & 0,45 & \multirow{4}{*}{4,962} & \multirow{4}{*}{0,002} \\
\hline & Lise & 125 & 1,89 & 0,63 & & \\
\hline & Ön lisans & 120 & 2,11 & 0,73 & & \\
\hline & Lisans & 20 & 1,84 & 0,45 & & \\
\hline
\end{tabular}

Katılımcıların eğitim durum değişkenine göre İKY uygulamaları farklılaşması ve İYY ANOVA analizi sonucuna göre; IYYY $\mathrm{p}<0,05$ olduğundan anlamlı bir farklılık belirlenmiş, İKY uygulamaları $\mathrm{p}>0,05$ olduğundan anlamlı bir farklıl1k belirlenmemiştir. Bu bağlamda IYYY katılımcıların eğitim durumuna göre bir farklılık göstermektedir (Tablo 7). Bu sonuçlara göre; H10a hipotezi ret edilirken, H10b hipotezi kabul edilmektedir. 
Tablo 8: Katılımcıların turizm sektöründe çalışma süresi değişkenine göre insan kaynakları yönetimi uygulamaları ve iş yaşamında yalnızlık farklılaşması

\begin{tabular}{|c|c|c|c|c|c|c|}
\hline & & f & Ort. & s.s. & $\mathbf{F}$ & $\mathbf{p}$ \\
\hline \multirow{6}{*}{$\begin{array}{l}\text { İnsan Kaynakları } \\
\text { Yönetimi Uygulamaları }\end{array}$} & $0-1$ yıl arasında & 10 & 3,82 & 0,62 & \multirow{6}{*}{7,001} & \multirow{6}{*}{$\mathbf{0 , 0 0 0}$} \\
\hline & 2-3 yil arasinda & 45 & 4,32 & 0,87 & & \\
\hline & 4-5 yil arasinda & 85 & 4,49 & 0,44 & & \\
\hline & 6-7 yil arasinda & 30 & 4,07 & 0,30 & & \\
\hline & 8-9 yıl arasinda & 40 & 4,72 & 0,34 & & \\
\hline & 10 y1l ve üzeri & 100 & 4,21 & 0,81 & & \\
\hline \multirow{6}{*}{ İş yaşamında Yalnızlık } & $0-1$ yil arasinda & 10 & 2,09 & 0,30 & \multirow{6}{*}{6,141} & \multirow{6}{*}{$\mathbf{0 , 0 0 0}$} \\
\hline & 2-3 y1l arasinda & 45 & 1,81 & 0,65 & & \\
\hline & 4-5 y1l arasinda & 85 & 1,94 & 0,64 & & \\
\hline & 6-7 yil arasinda & 30 & 2,34 & 0,48 & & \\
\hline & 8-9 y1l arasinda & 40 & 1,58 & 0,51 & & \\
\hline & 10 yıl ve üzeri & 100 & 2,03 & 0,70 & & \\
\hline
\end{tabular}

Katılımcıların turizm sektöründe çalışma süresi değişkenine göre IKKY uygulamaları ve IYY farklılaşması ANOVA testi sonucuna göre $\mathrm{p}<0,05$ olduğundan anlamlı bir farklılık belirlenmiştir. Bu bağlamda İKY uygulamaları ve İYY katılımcıların turizm sektöründe çalışma süresi değişkenine göre bir farklılık göstermektedir. Bununla birlikte ortalamaya bakıldığında turizm sektöründe 8-9 yıl arasında çalışan katılımcılar diğer katılımcılara göre daha fazla IKKY uygulamalarının olduğunu düşünmekte ve IYYY göstermektedir (Tablo 8). Bu sonuçlara göre; H11a ve H11b hipotezleri kabul edilmektedir.

Tablo 9: Katılımcıların işletmede çalışma süresi değişkenine göre insan kaynakları yönetimi uygulamaları ve iş yaşamında yalnızlık farklılaşması

\begin{tabular}{|c|c|c|c|c|c|c|}
\hline & & f & Ort. & S.S. & $\mathbf{F}$ & $\mathbf{p}$ \\
\hline \multirow{6}{*}{$\begin{array}{l}\text { İnsan Kaynakları Yönetimi } \\
\text { Uygulamaları }\end{array}$} & $0-1$ yıl arasında & 65 & 4,26 & 0,71 & \multirow{6}{*}{9,386} & \multirow{6}{*}{$\mathbf{0 , 0 0 0}$} \\
\hline & 2-3 yıl arasinda & 135 & 4,45 & 0,51 & & \\
\hline & 4-5 yıl arasında & 55 & 4,22 & 0,75 & & \\
\hline & 6-7 y1l arasinda & 15 & 3,48 & 1,13 & & \\
\hline & 8-9 yıl arasında & 10 & 4,82 & 0,15 & & \\
\hline & 10 yıl ve üzeri & 30 & 4,44 & 0,45 & & \\
\hline \multirow{6}{*}{ İş yaşamında Yalnızlık } & $0-1$ yll arasinda & 65 & 2,02 & 0,67 & \multirow{6}{*}{5,843} & \multirow{6}{*}{$\mathbf{0 , 0 0 0}$} \\
\hline & 2-3 yıl arasinda & 135 & 1,91 & 0,62 & & \\
\hline & $4-5$ yıl arasinda & 55 & 1,91 & 0,63 & & \\
\hline & 6-7 y1l arasinda & 15 & 2,58 & 0,63 & & \\
\hline & 8-9 yıl arasinda & 10 & 1,25 & 0,00 & & \\
\hline & 10 yıl ve üzeri & 30 & 1,94 & 0,65 & & \\
\hline
\end{tabular}

Katılımcıların işletmede çalışma süresi değişkenine göre İKY uygulamaları ve İYY farklılaşması ANOVA testi sonucuna göre $\mathrm{p}<0,05$ olduğundan anlamlı bir farklılık belirlenmiştir. $\mathrm{Bu}$ bağlamda İKY uygulamaları ve İYY katılımcıların işletmede çalışma süresi değişkenine göre bir farkl11ık göstermektedir (Tablo 9). Bu sonuçlara göre; H12a ve H12b hipotezleri kabul edilmektedir.

\section{Sonuç}

Günümüz otel işletmelerinde insan kaynağından en etkin bir biçimde fayda sağlamak zorunlu hale gelmiş bulunmaktadır. İnsan kaynağının etkinliği insan kaynakları yönetiminin uygulamalarına bağlı olarak şekillenmekte ve çalışanlar söz konusu uygulamalara göre davranış sergilemektedir. Otel işletmelerinde İKY uygulamalarından ödüllendirme, ücret, eğitim uygulamaları ve performans değerlendirme, işgören ile iletişim ve kariyer sistemine bağlı olarak çalışanların sosyal arkadaşlıkları ve duygusal yoksunlukları yani iş yaşamında yalnızlıkları önem 
arz etmektedir. Çünkü otel işletmelerin verimliliği, rekabet üstünlüğü elde etmesi, sürdürülebilirliğini sağlaması için insan kaynakları yönetimine bağlı olarak iş yaşamında sosyal arkadaşlığı olmayan ve duygusal yoksunluğa sahip çalışanların bulunması çalışanların performansını, iş tatminini ve motivasyonunu önemli ölçüde olumsuz etkileyebilmekte ve otel işletmelerine zarar verebilmektedir. Bu bağlamda otel işletmelerinin insan kaynağından etkin bir şekilde faydayı sağlayabilmesi noktasında İKY uygulamalarıyla birlikte çalışanların iş yaşamında yalnızlıklarının azaltılması gerekmektedir.

Otel işletmelerinde İKY uygulamaları ile çalışanların iş yaşamında yalnızlıkları arasındaki iliş̧kinin belirlenmesine yönelik yapılan bu araştırmada korelasyon analizinin sonucuna göre otel işletmelerinde IKKY uygulamaları ile IYYY arasında anlamlı düzeyde negatif yönlü yüksek bir ilişki olduğu tespit edilmiştir. Bu kapsamda İKY uygulamalarının etkinliği arttıkça çalışanların IYYY, sosyal arkadaşlık ve duygusal yoksunluk düzeylerinin azalacağını söylemek mümkündür. Bununla birlikte regresyon analizi sonuçlarına göre İYY bağımlı değişkeni İKY uygulamaları tarafindan açıklanabilmekte ve anlamlılık değerlerine göre bağımlı ve bağımsız değişkenler arasındaki tüm ilişkilerin anlamlı olduğu sonucuna ulaşılmıştır. Araştırmada katılımcıların cinsiyet, yaş, turizm sektöründe ve işletmede çalışma süresine göre İKY uygulamaları ve iş yaşamında yalnızlığın, katılımcıların medeni durum değişkenine göre İKY uygulamalarının, katılımcıların eğitim durum değişkenine göre iş yaşamında yalnızlığın farklılık gösterdiği belirlenmiştir. Bu sonuçlara göre araştırmada H1, H2a, H2b, H3a, H3b, H4, H4b, H5a, H5b, H6a, H6b, H7a, H7b, H8a, H9a, H9b H10b, H11a, H11b, H12a ve H12b hipotezleri kabul edilirken, H8b ve H10a hipotezleri ret edilmektedir.

Araştırmada yapılan analiz sonuçlarından yola çıkılarak İKY uygulamalarından ödüllendirme, ücret sistemi, eğitim uygulamaları ve performans değerlendirme, iş gören ile iletişim ve kariyer sistemi kapsamında otel işletmelerinde üstün başarı gösterenlere, ilave olarak çeşitli ödüllerin verilmesi, çalışanların aldıkları ödüllerin göstermiş oldukları başarılara ve performansa bağlı olması, adil bir ödül sisteminin bulunması, aldıkları ücretin kendileri ve ailelerinin ihtiyaçlarını karşılaması bakımından yeterli olması, harcadıkları gayretin tam karşılığı olan bir ücret alması, çalışanlara, ihtiyaç olduğunda yeterli ölçüde eğitim verilmesi ve çalışanların aldıkları eğitimler sayesinde yeni beceriler kazanması, otelde adil bir performans değerlendirme sisteminin olması, çalışanlar ile yönetici arasında iletişim sorunlarının yaşanmaması, çalışanların fikir ve önerilerine açık ve saygılı davranılması, otelde işini iyi yapan çalışanın adil bir şekilde terfi ettirilmesi ve terfi sisteminin çalışanların beklentilerini karşılayabilecek düzeyde yeterli olmasıyla çalışanlar çalışma arkadaşlarının kendilerine mesafeli durduklarını hissetmeyebilecek, diğer çalışanlarla arasına mesafe koymayabilecek, kendilerini çalışma arkadaşlarından duygusal olarak uzak hissetmeyebilecek, oteldeki ilişkilerinden memnuniyet duyabilecek, otelde dostluk anlayış1 baskın olabilecek, çalışma arkadaşlarıyla birlikteyken çoğu zaman kendini dışlanmış, genel bir boşluk duygusu içinde ve diğer çalışanlarla birlikte arasında bir kopukluk olduğunu düşünmeyebilecektir. $\mathrm{Bu}$ sayede çalışan performansı artarak yaratıc1lığını kullanabilecek, motivasyonu yüksek ve işinden tatmin olabilecek işten ayrılma niyetinde bulunmayabilecektir. Bu durum otel işletmelerinde iş gören devir hızını düşürerek işletmeye ek bir maliyet oluşturmayabilecektir.

$\mathrm{Bu}$ çalışma turizm işletmelerinden sadece otel işletmelerinde istihdam edilen işgörenleri kapsamış olup; yiyecek, içecek işletmeleri, ulaştırma ve havayolu işletmeleri ve seyahat işletmeleri kapsam dışı bırakılmış ve sadece İKY ve İYY arasındaki ilişki ele alınmıştır. Bununla birlikte çalışma sonuçları çalışma kapsamında kullanılan ölçekten elde edilen veriler ile sınırlı olup IKKY ile ilişkisi muhtemel olan psikolojik sözleşme ihlali, örgütsel uyum, örgütsel güven, örgütsel sessizlik gibi diğer faktörler ele alınmamıştır. Bu bağlamda bundan sonraki araştırmalarda bu araştırmadaki sinırlıliklar dikkate alınabilir. 


\section{Kaynakça}

Akın, Ö., Erdost Çolak, E. (2012). İnsan kaynakları yönetimi uygulamalarıyla örgütsel performans arasındaki ilişki üzerine bir araştırma, Çankırı Karatekin Üniversitesi İktisadi ve İdari Bilimler Fakültesi Dergisi, 2(2): 85-114.

Armstrong, M. (2010). Armstrong's essential human resource management practice - A guide people management, US Kogan Page Limited.

Ataay, İ. D., Acar, A. C. (2015). Ücret Yönetimi, İnsan Kaynakları Yönetimi içinde Ed.: Sadullah, Ö., Uyargil, C., Acar, A. C., Özçelik, A. O., Dündar, G., Ataay, İ. D., Adal, Z., Tüzüner, L., Yenilenmiş 7. Baskı, Beta Basım Yayım Dağıtım A.Ş.

Barutçugil, İ. (2004). Stratejik İnsan Kaynakları Yönetimi, Kariyer Yayınc1lı,, İstanbul.

Boz, H. (2019). Algılanan insan kaynakları yönetimi uygulamalarının işten ayrılma niyetine etkisinde çalışmaya tutkunluğun aracılık rolü: Turizm işgörenleri üzerine bir araştırma. Mehmet Akif Ersoy Üniversitesi İktisadi ve İdari Bilimler Fakültesi Dergisi, 6 (2): 300-315.

Calp, M. H. (2016). İşletmelerde uygulanan insan kaynakları yönetiminde veritabanı kullanımının önemi. Gazi Üniversitesi Iktisadi ve İdari Bilimler Dergisi, 18(2): 539-557.

Coffie R. B., Boateng, K. A., Coffie F.(2018). Achieving organizational commitment through HRM practices: The Ghanaian banking sector experience, International Journal of Business and Management, 13(5): 171-184.

Çalışkan, E. (2010). The impact of strategic human resource management on organizational performance. Journal of Naval Sciences and Engineering, 6(2): 100-116.

Çavuş, M.F., Biçer, M. (2019). Insan Kaynakları Yönetimi Çerçevesinde Sosyalleşmek ya da Yabancılaşmak. Ankara: Gazi Kitabevi.

Dawwas, M. I. F., Zahare, I. (2014). Testing the direct and indirect relationship between human resource management and turnover intention in a non-Western context of the Palestine. Journal of Advanced Social Research, 4(6): 10-22.

Demirbaş, B., Haşit, G. (2016). İşyerinde yalnızlık ve işten ayrılma niyetine etkisi: Akademisyenler üzerine bir uygulama, Anadolu Üniversitesi Sosyal Bilimler Dergisi, 16(1):137-158.

Deniz, S . (2019). Effect Of Loneliness In The Workplace On Employees' Job Performance: A Study For Hospital Employees. International Journal of Health Services Research and Policy, 4(3), 214-224.

Doğan T., Çetin B., Sungur, M. Z. (2009). İş yaşamında yalnızlık ölçeği türkçe formunun geçerlilik ve güvenilirlik çalışması, Anadolu Psikiyatri Dergisi, 10: 271-277.

Erdil, O., Alpkan, L. H., Biber, L. (2004). İnsan kaynakları uygulamalarıyla örgütsel performans arasındaki ilişkileri araştırmaya yönelik bir inceleme. Dokuz Eylül Üniversitesi İktisadi ve İdari Bilimler Fakültesi Dergisi, 19(2): 101-122.

Erdirençelebi, M., Ertürk, E. (2018). Çalışanların örgütsel yalnızlık algısının iş tatmini ve işten ayrılma niyeti üzerine etkileri. Gaziantep University Journal of Social Sciences, 17(2): 603-617.

Ernst, J. M., Cacioppo, J. T. (1999). Lonely hearts: Psychological perspectives on loneliness. Applied and Preventive Psychology, 8: 1-22.

Ertosun, Ö.G., Erdil, O. (2012). The effecets of loneliness on employees' commitment and intention to leave, Procedia-Social and Behavioral Sciences, 41: 469-476. 
Frasch, B. K., Shadovitz, D., Shelly, J. (2009). There's No Whining in HR. Human Resource Executive Online, June 30, , http://www.hreonline.com/HRE/story.jsp?storyId=227738167. Erişim: 17 Nisan 2020

Frye, M.B. (2004). Equity-based compensation for employees: Firm performance and determinants. Journal of Financial Research, 27(1): 31-54.

Güler, E. Ç. (2006). İşletmelerin e-insan kaynakları yönetimi ve e-işe alım süreçlerindeki gelişmeler. Ege Akademik Bakış Dergisi, 6(1): 17-23.

Guchait, P., Cho, S. (2010). The impact of human resource management practices on intention to leave of employees in the service industry in India: The mediating role of organizational commitment. The International Journal of Human Resource Management, 21(8): 12281247.

Güler, M., Turgut, H., Basım, H.N. (2018). İnsan kaynakları yönetimi uygulamalarının işe yabancılaşma üzerindeki etkisi: Sessizliğin ve ayrımcıllı̆ğn düzenleyicilik rolü. Işsletme Araştırmaları Dergisi, 10(3): 804-820.

Gürbüz, S., Bekmezci, M. (2012). İnsan kaynakları yönetimi uygulamalarının bilgi işçilerinin işten ayrılma niyetine etkisinde duygusal bağlılığın aracılık ve düzenleyicilik rolü. Ístanbul Üniversitesi Işletme Fakültesi Dergisi, 41(2): 189-213.

Hassan, S. (2016). Impact of HRM practices on employee's performance. International Journal of Academic Research in Accounting, Finance and Management Sciences, 6(1): 15-22.

Itika, J. (2011) Fundamentals of human resources management: Emerging experiences from Africa. African Public Administration and Management Series, 2, African Studies Centre.

Jiang, K., Lepak, D.P., Hu, J., Baer, J.C. (2012). How does human resource management influence organizational outcomes? A meta-analytic investigation of mediating mechanisms. Academy of Management Journal, 55(6): 1264-1294.

Keser, A., Karaduman, M. (2014). İş yaşamında yalnızlık algısının örgütsel vatandaşlık davranışı ile ilişkisi ve öğretmenler üzerinde bir araştırma. Hak-İs Uluslararası Emek ve Toplum Dergisi, 3(7): 178-197.

Koçel T. (2014) İşletme Yöneticiliği. 15. Baskı. Beta Basım A.Ş., İstanbul.

Long, C. S., Perumal, P. (2014). Examining the impact of human resource management practices on employees' turnover intention. International Journal of Business and Society, 15(1): 111-126.

Mahapatro, B. (2010). Human Resource Management, New Age International Ltd., Publishers: New Delhi.

Mercan, N., Oyur, E., Alamur, B., Gül, S., Bengül, S. (2012). İşyeri yalnızlığı ve sosyal fobi arasındaki ilișkiye yönelik bir araștırma. Organizasyon ve Yönetim Bilimleri Dergisi. 4(1), 213-226.

Ocen, E., Francis, K., Angundaru, G. (2017). The role of training in building employee commitment: The mediating effect of job satisfaction. European Journal of Training and Development, 41(9): 742-757.

Osibanjo, A. O., Adeniji, A. A., (2012). Human resource management: Theory and practice. Pumark Nigeria Limited. 
Özutku, H., Çetinkaya, M. (2012). Stratejik insan kaynakları yönetimi ve firma performansı arasındaki ilişkide içsel ve dişsal uyumun moderatör etkisi: Türk otomotiv sektöründe bir alan araştırmas1. Ege Akademik Bakış, 12(3): 351-367.

Patrick, H.A., Kumar, A. (2011). Career management, employee development and performance in Indian information technology organisations. Business Management Dynamics, 1(5): 2431.

Paşaoğlu, D. (2015). Analysis of the relationship between human resources management practices and organizational commitment from a strategic perspective: Findings from the banking industry. Procedia-Social and Behavioral Sciences, 207: 315-324.

Perlman, D., Peplau, L. (1998). Loneliness. In: Friedman, H.S., Ed., Encyclopedia of Mental Health, Vol. 2, Academic Press, San Diego, 571-581.

Sadullah, Ö. (2015). Insan Kaynakları Yönetimine Giriş: Insan Kaynakları Yönetiminin Tanımı, Önemi ve Çevresel Faktörler, İnsan Kaynakları Yönetimi içinde Ed.: Sadullah, Ö., Uyargil, C., Acar, A. C., Özçelik, A. O., Dündar, G., Ataay, İ. D., Adal, Z., Tüzüner, L., Yenilenmiş 7. Baskı, Beta Basım Yayım Dağıtım A.Ş.

Singh, K. (2004). Impact of HR practices on perceived firm performance in India. Asia Pacific Journal of Human Resources, 42: 301- 317.

Soran, S., Serin, E., Balkan, M. (2016). İnsan kaynakları yönetim süreçlerinin performansa etkisi: Örgütsel öğrenmenin aracılık rolü ve bir uygulama. Doğuş Üniversitesi Dergisi, 17(1): 114.

Şişman, M., Turan, S. (2004). Bazı örgütsel değişkenler açısından çalışanların iş doyumu ve sosyal-duygusal yalnızlık düzeyleri (MEB şube müdür adayları üzerinde bir araştırma). Osmangazi Üniversitesi Sosyal Bilimler Dergisi, 5(1): 117-128.

Türk Dil Kurumu (TDK), (2020). https://sozluk.gov.tr/. Erişim: 20.04.2020.

Türen, U., Gökmen Y., Tokmak, İ. (2013). İnsan kaynakları yönetimi uygulamalarının işletme performansına etkisi: İşletmelerin sahip oldukları bilgi ve iletişim teknolojileri kabiliyetlerinin arac1lık rolü. Business and Economics Research Journal, 4(4): 103-129.

Wright, S.L. (2005). Loneliness in The Workplace. Unpublished Doctoral Dissertation, Christchurch (New Zealand) University Of Canterbury.

Wright S.L, Burt C.D.B., Strongman, K.T. (2006). Loneliness in the workplace: Construct Definition and Scale Development. New Zealand Journal of Psychology, 35(2): 59-68.

Yakut, S., Certel, H. (2016). Öğretmenlerde yalnızlık düzeyinin çeşitli değişkenler açısından incelenmesi. Birey ve Toplum, 6(11): 169-193.

Yeşil, S., Özel, B. (2019). İnsan kaynakları yönetimi uygulamalarının örgütsel bağlılık ve bireysel performansa etkisi: Banka çalışanları üzerinde bir araştırma. Kahramanmaraş Sütçü İmam Üniversitesi İktisadi ve İdari Bilimler Fakültesi Dergisi, 9(2): 13-34. 